\title{
Paclitaxel and CYC3, an aurora kinase A inhibitor, synergise in pancreatic cancer cells but not bone marrow precursor cells
}

\author{
Y Lin ${ }^{*, 1,2}$, FM Richards*,1,2, B-F Krippendorff',2, JL Bramhall ${ }^{1,2}$, JA Harrington ${ }^{1,2}$, TE Bapiro ${ }^{1,2}$, A Robertson ${ }^{3}$, \\ D Zheleva ${ }^{3}$ and DI Jodrell ${ }^{1,2}$
}

'Department Of Oncology, University of Cambridge, Cambridge CB2 ORE, UK; ${ }^{2}$ Cancer Research UK, Cambridge Research Institute, Li Ka Shing Centre, Robinson Way, Box 278, Cambridge CB2 ORE, UK; ${ }^{3}$ Cyclacel Ltd, I, James Lindsay Place, Dundee DDI 5JJ, UK

BACKGROUND: Amplification of aurora kinase A (AK-A) overrides the mitotic spindle assembly checkpoint, inducing resistance to taxanes. RNA interference targeting AK-A in human pancreatic cancer cell lines enhanced taxane chemosensitivity. In this study, a novel AK-A inhibitor, CYC3, was investigated in pancreatic cancer cell lines, in combination with paclitaxel.

METHODS: Western blot, flow cytometry and immunostaining were used to investigate the specificity of CYC3. Sulforhodamine B staining, time-lapse microscopy and colony-formation assays were employed to evaluate the cytotoxic effect of CYC3 and paclitaxel. Human colony-forming unit of granulocyte and macrophage (CFU-GM) cells were used to compare the effect in tumour and normal tissue.

RESULTS: CYC3 was shown to be a specific AK-A inhibitor. Three nanomolar paclitaxel (growth inhibition 50\% (GI 50 ) 3 nM in PANC-I, 5.I nM in MIA PaCa-2) in combination with I $\mu \mathrm{M}$ CYC3 ( $\mathrm{Gl}_{50}$ I.I $\mu \mathrm{M}$ in MIA PaCa2 and $2 \mu \mathrm{M}$ in PANC-I) was synergistic in inhibiting pancreatic cell growth and causing mitotic arrest, achieving similar effects to 10 -fold higher concentrations of paclitaxel (30 nM). In CFU-GM cells, the effect of the combination was simply additive, displaying significantly less myelotoxicity compared with high concentrations of paclitaxel (30 nm; 60-70\% vs 100\% inhibition).

CONCLUSION: The combination of lower doses of paclitaxel and CYC3 merits further investigation with the potential for an improved therapeutic index in vivo.

British Journal of Cancer (2012) I 07, 1692-1701. doi:I0.1038/bjc.2012.450 www.bjcancer.com

Published online 4 October 2012

(C) 2012 Cancer Research UK

Keywords: pancreatic cancer; paclitaxel; CYC3; mitotic inhibitor; combination treatment

Aurora kinases (AKs) are a family of serine/threonine kinases that are important for mitosis. In mammals, there are three members in this family, AK-A, AK-B and AK-C (Gautschi et al, 2008). Both $\mathrm{AK}-\mathrm{A}$ and $\mathrm{AK}-\mathrm{B}$ are overexpressed in a number of cancers, including breast, lung, bladder and pancreas (Gautschi et al, 2008). Given their association with cancer, both AK-A and AK-B have become targets for cancer therapy (Lok et al, 2010). Various selective or non-selective inhibitors of AKs have been developed and tested as potential cancer therapeutics in clinical or preclinical studies (Cheung et al, 2009; Kitzen et al, 2010). The majority of these compounds are pan-aurora inhibitors. Those drugs under evaluation for use in solid tumours that are reported to be specific for AK-A include ENMD-2076, which also has VEGFR inhibitor activity. It showed promising anti-tumour activity, especially in ovarian cancer in a phase I trial (Diamond et al, 2011), but it has also recently been shown to inhibit AK-B at concentrations that are cytotoxic (Wang et al, 2010b), so it is not an AK-A-specific inhibitor in vivo. MK5108 has more than 200-fold selectivity for AK-A over AK-B and appears to be AK-A-specific in cells and in xenograft tumours (Shimomura et al, 2010a). MK5108 is being

*Correspondence: Dr Y Lin; E-mail: yao.lin@cancer.org.uk or Dr FM Richards; E-mail: frances.richards@cancer.org.uk

Revised 30 August 2012; accepted 7 September 2012; published online 4 October 2012 tested in a phase I trial in advanced solid tumours with and without docetaxel (Minton et al, 2010). Another AK-A-specific inhibitor, MLN8054, was discontinued because of benzodiazepinelike effects (Dees et al, 2010; Macarulla et al, 2010), and has been replaced by MLN8237 (alisertib; Manfredi et al, 2011b). MLN8237 is now in phase II trials in lung, breast, head and neck, and gastrointestinal cancers (Sharma et al, 2011). To our knowledge, no AK-A-specific inhibitor is being investigated in clinical trials in pancreatic cancer.

Pancreatic ductal adenocarcinoma is a particularly lethal cancer with a cumulative 5-year survival rate of less than 5\% (Warshaw and Fernandez-del Castillo, 1992). It is resistant to most current forms of cytotoxic chemotherapy and ionising radiation ( $\mathrm{Li}$ et al, 2010). Overexpression of AK-A has been shown in pancreatic cancer cell lines and tissues (Li et al, 2003; Rojanala et al, 2004). Of relevance to our studies, amplification of AK-A has been reported to induce resistance to taxanes (Anand et al, 2003). Knockdown of AK-A by RNA interference in pancreatic cancer cell lines not only led to growth inhibition, cell cycle arrest and apoptosis (Hata et al, 2005b; Warner et al, 2006), but also enhanced the taxane chemosensitivity in these cells (Hata et al, 2005b). Therefore, cotreatment of an AK-A-specific inhibitor with paclitaxel may be an intriguing drug combination for pancreatic cancer.

Bone marrow (BM) is very sensitive to many anti-proliferative agents (Negro et al, 2001). A clinical side effect of paclitaxel treatment is neutropenia, caused by damage to the neutrophil 
progenitor cells in BM (Rowinsky et al, 1993). A concern in considering combinations of $\mathrm{AK}$ inhibitors and taxanes is that in the phase I clinical trials of several different dual inhibitors for both $\mathrm{AK}-\mathrm{A}$ and $\mathrm{AK}-\mathrm{B}$, neutropenia is one of the major side effects observed (Cheung et al, 2009). In pre-clinical studies to assess potential myelotoxicity, the colony-forming unit of granulocyte and macrophage (CFU-GM) assay has been optimised and validated to predict potential drug myelotoxicity in vitro (Parent-Massin, 2001), but to our knowledge this has not been used to test AK-A inhibitors.

In this report, an AK-A-specific inhibitor CYC3 from Cyclacel Ltd has been tested alone and in combination with paclitaxel in pancreatic cancer cell lines. To distinguish additivity from synergy, we employed growth inhibition assays (by sulforhodamine B (SRB) staining) and mathematical modelling to search for real synergistic combinations. Later, we confirmed the synergy by time-lapse microscopy and colony-formation assays. In addition, we investigated the potential myelotoxicity of the synergistic combination identified using a CFU-GM assay with human BM cells.

\section{MATERIALS AND METHODS}

\section{Cell culture}

PANC-1 and MIA PaCa-2 (human pancreatic carcinoma) cells obtained from the European Collection of Cell Cultures (ECACC; Health Protection Agency, Salisbury, UK) were verified by STR genotyping and tested negative for mycoplasma. They were cultured in Dulbecco's modified Eagle's medium (DMEM) supplemented with $10 \%$ fetal calf serum at $37{ }^{\circ} \mathrm{C}$ and $5 \% \mathrm{CO}_{2}$. Paclitaxel (catalogue number 1097) was obtained from Tocris Bioscience (Bristol, UK). Paclitaxel and CYC3 were dissolved in dimethylsulphoxide (DMSO) and then diluted in culture medium to a final concentration of $0.2 \%$ DMSO.

\section{Sulforhodamine assay}

Cells were seeded in 96-well plates at concentrations of 3000 PANC-1 cells per well or 2000 MIA PaCa-2 cells per well. Twenty-four hours later, cells were treated with drugs for $72 \mathrm{~h}$. Then, cells were fixed with trichloroacetic acid and stained with SRB (Skehan et al, 1990). Fluorescence was quantified using an Infinite 200 PRO plate reader (Tecan, Reading, UK) at a wavelength of $545 \mathrm{~nm}$. Drug-treated wells were compared with solvent control wells, and the concentration of drug that resulted in $50 \%$ of the cell growth of the solvent control was designated as the $\mathrm{GI}_{50}$ concentration, calculated using Graphpad PRISM 5 (Graphpad Software, La Jolla, CA, USA). At least three biological replicates were performed for each assay.

\section{Synergy calculation}

Ninety-six-well plates were treated with a dilution series of each drug in an $8 \times 8$ checkerboard pattern of combinations. After SRB staining to obtain the growth inhibition data, we used software that we developed to identify synergistic drug combinations (SynergySurface, www.synergysurface.com; Figure 3). The single agent inhibition values were used to calculate a drug combination surface under the assumption of an additive effect. To obtain this additive surface, different models of additivity can be used (Bliss, Loewe and the Highest Single Agent). Details of the three models and their relative advantages can be found in previous publications (Jonker et al, 2005; Fitzgerald et al, 2006a); we used the Bliss model in these studies because it assumes independent mechanisms of action of the two drugs. Regions of synergy are then detected by comparing obtained data from a combination with the calculated additive effect. This is done by subtracting the calculated additive inhibition values from the measured inhibition to obtain the final difference values. In the final synergy surface, positive values hence indicate synergy regions, whereas negative difference values identify antagonistic effects.

\section{Time-lapse microscopy}

Cells were seeded in 96-well plates, and $24 \mathrm{~h}$ later cells were exposed to drug and imaged every $3 \mathrm{~h}$ by time-lapse microscopy using an Incucyte (Essen Bioscience, Welwyn Garden City, UK) for $72 \mathrm{~h}$. The cell confluence was calculated using the Incucyte software (2010A, Rev2).

\section{Cancer cell colony-formation assay}

A total of 20000 cells were seeded in 6-well plates, and $24 \mathrm{~h}$ later cells were exposed to drugs for $72 \mathrm{~h}$, then counted. Equal numbers of cells $(1000,2500$ and 5000) from each sample were then seeded in $6 \mathrm{~cm}$ plates and left to grow for 7 days. After that, cells were fixed with 70\% methanol and stained with 5\% Giemsa (Sigma, Gillingham, UK). Colony numbers were calculated using ImageQuanTL (GE Healthcare, Little Chalfont, UK).

\section{Immunostaining}

A total of 5000 cells were seeded in 8-well chamber slides (Ibidi, München, Germany) and treated with drugs $24 \mathrm{~h}$ later. After treatment, cells were fixed with $4 \%$ paraformaldehyde in PBS, permeabilised with $0.3 \%$ Triton X-100 in PBS, then stained with antibodies and counterstained with DAPI. The primary antibodies were anti- $\alpha$-tubulin (T5168, Sigma) and anti-p-AK-A (T288; 3079, Cell Signalling Technologies, Danvers, MA, USA); secondary antibodies were anti-rabbit IgG Alexa 647 (4414, Cell Signalling Technologies) and anti-mouse IgG Alexa 488 (4408, Cell Signalling Technologies). The confocal image was taken using a Leica IR Laser microscope (Milton Keynes, UK). The image quantification was done using Icys research imaging cytometer (Compucyte, Westwood, MA, USA) and analysed as described in http:// www.compucyte.com/cellcycle.htm.

\section{Western blot}

For a typical experiment, proteins were extracted from cells using RIPA buffer (50 mm Tris HCl pH 8.0, 150 mu NaCl, 1\% NP-40, 0.5\% sodium deoxycholate, $0.1 \%$ SDS) and equal amounts (measured using Bradford assay reagent (Biorad, Hemel Hempstead, UK)) were separated by SDS-PAGE using Novex Bris-Tris $4-12 \%$ gels (Invitrogen, Paisley, UK) in MOPs buffer (Invitrogen) and then transferred to nitrocellulose membrane (Invitrogen). After blocking with Odyssey blocking buffer (LI-COR Biosciences, Lincoln, NE, USA), blots were stained with primary antibodies from Cell Signalling Technologies: anti-phospho AK-A/B/C (2914), anti-AK-A (3092S), anti-cleaved PARP (5625S); from Abcam (Cambridge, UK): anti- $\beta$-actin (ab6276), anti-AK-B (ab2254); and from Millipore (Watford, UK): anti-p-H3 S10 (06-570). Secondary antibodies from LiCOR Biosciences were IRDye 680 - or $800 \mathrm{CW}$ conjugated goat anti-mouse or anti-rabbit IgGs (926-32210, 926-32211, 926-32220, 926-32221). The blots were imaged and quantified using the Odyssey Infrared Imaging System (LI-COR Biosciences). To detect phospho-aurora A in PANC-1 and MiaPaCa-2 cells, it was necessary to first increase the level of aurora A expression by arresting the cells in mitosis with nocodazole, because the level of aurora A was too low in asynchronous cell populations.

\section{Flow cytometry}

In a typical experiment, cells were harvested by $0.05 \%$ trypsin, retaining the culture media containing floating cells. Cells were fixed with $70 \%$ ethanol, stained with propidium iodide solution $\left(0.1 \% \mathrm{v} / \mathrm{v}\right.$ Triton-X-100, $20 \mu \mathrm{g} \mathrm{ml}^{-1}$ propidium iodide, 
$0.2 \mathrm{mg} \mathrm{ml}^{-1}$ ribonuclease $\mathrm{A}$ in $\mathrm{PBS}$ ) and analysed using a $\mathrm{BD}$ FACSCalibur flow cytometer (Becton Dickinson, Oxford, UK). Machine configuration details and representative plots are shown in the Supplementary Methods). The cell cycle distribution of the samples was determined using FlowJo version 7.6.1 (Tree Star, Inc., Ashland, OR, USA).

\section{LC-MS/MS analysis of paclitaxel}

Cell pellets obtained after washing in PBS were fixed in ice-cold methanol $(70 \% \mathrm{v} / \mathrm{v})$ by vigorous vortexing, followed by incubation at $-80^{\circ} \mathrm{C}$ for $1 \mathrm{~h}$. The suspension was sonicated, and the cell extract from untreated cells was used to prepare calibration standards. An aliquot of the cell suspension $(200 \mu \mathrm{l})$ was added to $200 \mu \mathrm{l}$ of ice-cold acetonitrile $(100 \% \mathrm{v} / \mathrm{v})$ containing paclitaxel$\left[{ }^{2} \mathrm{H}_{5}\right]$ internal standard. After centrifugation, the supernatant was evaporated to dryness in a speedvac. For media, $25 \mu \mathrm{l}$ of the supernatant was processed in the same way as an aliquot of the cell suspension. The residue was reconstituted in acetonitrile $(50 \% \mathrm{v} / \mathrm{v})$ and $20 \mu \mathrm{l}$ was injected into a Dionex-Ultimate 3000 LC with autosampler using an Acquity UPLC HSS T3 $50 \mathrm{~mm} \times 2.1 \mathrm{~mm}$ i.d., $1.8 \mu \mathrm{m}$ column (Waters, Elstree, UK). The mobile phase was (A) $0.1 \%$ acetic acid: (acetonitrile: methanol, (1:1)) $70: 30$ and (B) $0.1 \%$ acetic acid: (acetonitrile: methanol, (1:1)) 10:90. The gradient, at a flow rate of $225 \mu \mathrm{min}^{-1}$, was $25 \%$ B for $0.2 \mathrm{~min}$, increased to $100 \%$ over $0.2 \mathrm{~min}$ and maintained at $100 \%$ for $2.8 \mathrm{~min}$, decreased to $25 \%$ over $0.2 \mathrm{~min}$ and maintained at $25 \%$ for $2.1 \mathrm{~min}$ to give a total run time of $5.5 \mathrm{~min}$. The LC-MS/MS was performed on an Applied Biosystems Sciex 4000 Q-trap mass spectrometer (Applied Biosystems, Carlsbad, CA, USA) equipped with a turbo-ionspray source and data was acquired using Analyst 1.4.2 software (Applied Biosystems). The mass spectrometry parameters were set essentially as described by Zhang et al (2011). Quantitation of the internal standard was done by multiple-reaction monitoring of the transition 881.4-308.1, with all other parameters identical to those used for paclitaxel.

\section{Colony-forming unit of granulocyte and macrophage assay frozen}

Human BM mononuclear cells and methylcellulose-based culture medium (MethoCult H4025 optimum without EPO) were purchased from Stem Cell Technologies (Grenoble, France). The cells were counted and suspended in MethoCult medium with or without drugs, and then $2 \times 10^{4}$ cells were plated in $35 \mathrm{~mm}$ petri dishes and cultured for 14 days as described in the manufacturer's manual, catalogue number 28404. Colonies (aggregates with more than 30 cells) were counted manually using a Nikon TS100 microscope (Nikon, Surrey, $\mathrm{UK}) ; \mathrm{IC}_{50}$ and $\mathrm{IC}_{90}$ were calculated using Graphpad PRISM 5.

\section{Kinase assays}

The $\mathrm{IC}_{50}$ values for purified proteins were determined as previously described (Wang et al, 2010a). The $\mathrm{IC}_{50}$ values were determined using XLfit software (IDBS, Surrey, UK). Apparent inhibition constants $\left(K_{\mathrm{i}}\right)$ were calculated from $\mathrm{IC}_{50}$ values and the appropriate $K_{\mathrm{m}}$ (ATP) values for each kinase using the method of Cheng and Prusoff (1973). Recombinant human AK-A and AK-B were purchased from Upstate Discovery (Dundee, UK). Aurora A kinase assays were performed using a $25-\mu \mathrm{l}$ reaction volume (25 mm $\beta$-glycerophosphate, $20 \mathrm{~m}$ Tris/ $\mathrm{HCl} \mathrm{pH} \mathrm{7.5,} 5 \mathrm{mkm}$ EGTA, $1 \mathrm{~mm}$ DTT, $1 \mathrm{~mm} \mathrm{Na}_{3} \mathrm{VO}_{4}, 10 \mu \mathrm{g}$ kemptide (peptide substrate) and recombinant $\mathrm{AK}-\mathrm{A}$ diluted in $20 \mathrm{~mm}$ Tris/ $\mathrm{HCl} \mathrm{pH} \mathrm{8,} \mathrm{containing}$ $0.5 \mathrm{mg} \mathrm{ml}^{-1} \mathrm{BSA}, 2.5 \%$ glycerol and $0.006 \%$ Brij-35. Reactions were started by the addition of $5 \mu \mathrm{l} \mathrm{Mg} / \mathrm{ATP} \operatorname{mix}\left(15 \mathrm{mM} \mathrm{MgCl}_{2}\right.$ and $100 \mu \mathrm{M}$ ATP, with $18.5 \mathrm{kBq} \gamma-{ }^{32} \mathrm{P}$-ATP per well) and incubated at $30{ }^{\circ} \mathrm{C}$ for $30 \mathrm{~min}$ before terminating by the addition of $25 \mu \mathrm{l} 75 \mathrm{~mm}$ $\mathrm{H}_{3} \mathrm{PO}_{4}$. Aurora B kinase assays were performed as for aurora A, except that before use aurora $\mathrm{B}$ was activated in a separate reaction at $30{ }^{\circ} \mathrm{C}$ for $60 \mathrm{~min}$ with inner centromeres protein (Upstate, Dundee, UK; Sessa et al, 2005). The conversion of $\mathrm{IC}_{50}$ to $K_{\mathrm{i}}$ values was as follows:

\begin{tabular}{lcccc}
\hline Enzyme & $\mathrm{IC}_{\mathbf{5 0}}(\boldsymbol{\mu} \mathrm{M})$ & $\boldsymbol{K}_{\mathrm{m}}(\mathrm{ATP})$ & Conversion factor $^{\mathrm{a}}$ & $\mathbf{K i}(\boldsymbol{\mu} \mathrm{M})$ \\
\hline Aurora A & 0.033 & 22 & 5.55 & 0.006 \\
Aurora B & 0.317 & 94 & 2.06 & 0.154 \\
\hline
\end{tabular}

${ }^{a}$ Conversion factor $=1+\left(K_{m}\right.$ ATP/reaction mixture (ATP)). Reaction mixture $($ ATP $)=100 \mu \mathrm{M}$

\section{M30 ELISA}

Cells $\left(10^{6}\right)$ were seeded in $10 \mathrm{~cm}$ plates. After drug treatment, the culture media were collected and floating cells were removed by centrifugation. Cleaved cytokeratin 18 induced by apoptosis was measured and quantified by M30 Apoptosense ELISA (PEVIVA $A B$, via Enzo Life Sciences (Exeter, UK) Ltd) according the manufacturer's manual.

\section{RESULTS}

\section{CYC3 is an AK-A-specific inhibitor}

CYC3 is a novel small-molecule inhibitor of AK-A. The inhibitor is a pyrimido-diazepine analogue (International Patent Number: WO 2009/040556 A1), which has high selectivity for AK-A in vitro. CYC3 inhibits AK-A at least 25-fold more potently than AK-B (Table 1) and has limited activity against a panel of 65 additional protein kinases (Supplementary Table S1). To evaluate the CYC3 effect in pancreatic cancer cells, we first investigated the ability of CYC3 to inhibit AK-A autophosphorylation on the T288 site (p-AK-A T288) in cells, which is a marker for AK-A kinase activity. In both MIA PaCa-2 and PANC-1 cells, CYC3 suppressed p-AK-A T288 in a dose-dependent manner (Figures $1 \mathrm{~A}$ and B). In flow cytometry analysis, CYC3 induced the accumulation of G2/M cells in a dose-dependent manner (Figure 1C). There was no observation of significant populations of cells with $8 \mathrm{~N}$ DNA content, which could have indicated endoreduplication, a sign of AK-B inhibition. In confocal microscopy experiments to investigate the effect of CYC3 in a single-cell manner, the p-AK-A T288 localised at the centrosomes as reported (Gautschi et al, 2008) and disappeared with CYC3 incubation (Figure 1D). Analysis of the cell cycle profile of the immunostained CYC3-treated cells using iCys (which can distinguish between cells in G2 and in $M$ phase) revealed an

Table I Structure and in vitro kinase selectivity of CYC3

\begin{tabular}{|c|c|c|}
\hline Pyrimido-diazepine core structure & Kinase & $K_{\mathrm{i}}(\mu \mathrm{M})$ \\
\hline $\begin{array}{ll}R_{6} & R_{7}\end{array}$ & $\begin{array}{c}\text { Aurora A } \\
\text { Aurora B } \\
\text { CDKI/cyclin B } \\
\text { CDK2/cyclin E } \\
\text { CDK4/cyclin DI } \\
\text { CDK7/cyclin H } \\
\text { CDK9/cyclin TI } \\
\text { PLKI } \\
\text { PLK4 } \\
\text { Flt3 } \\
\text { Lck } \\
\text { Src } \\
\text { hAbl }\end{array}$ & $\begin{array}{l}0.006 \\
0.154 \\
>20 \\
>20 \\
>20 \\
>20 \\
>20 \\
>20 \\
4.4 \\
5.1 \\
>20 \\
6.8 \\
4.3\end{array}$ \\
\hline
\end{tabular}


A

MIA PaCa-2

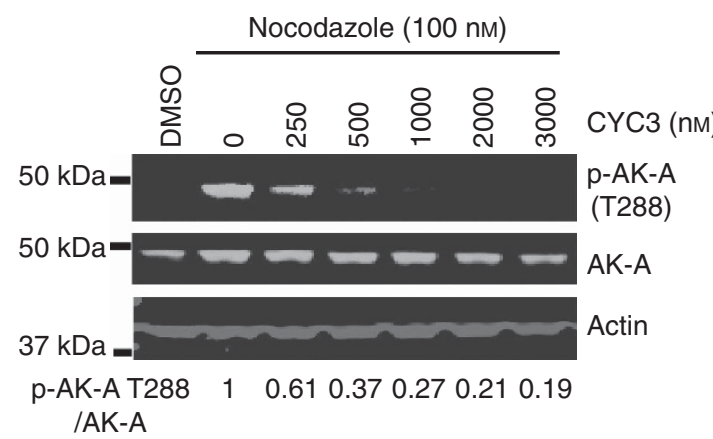

B

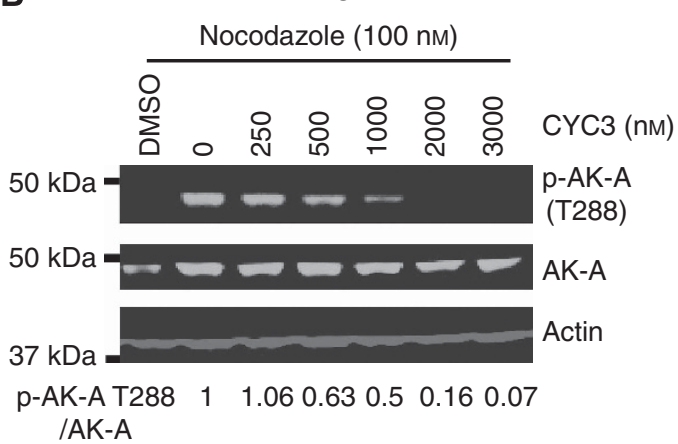

C DMSO CYC3 (nм)

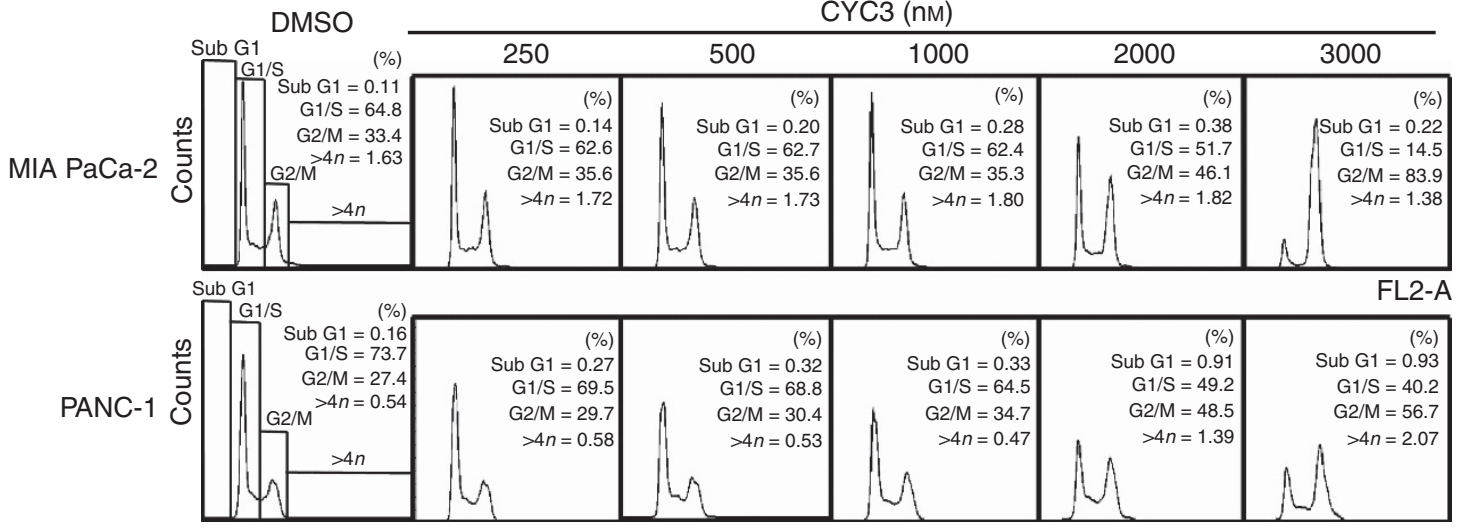

D MIA PaCa-2
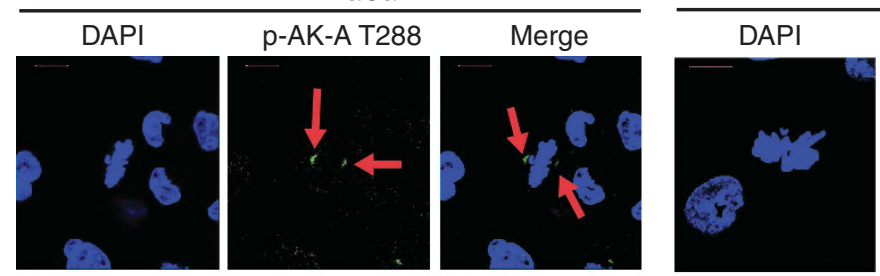

PANC-I

FL2-A

CYC3treated
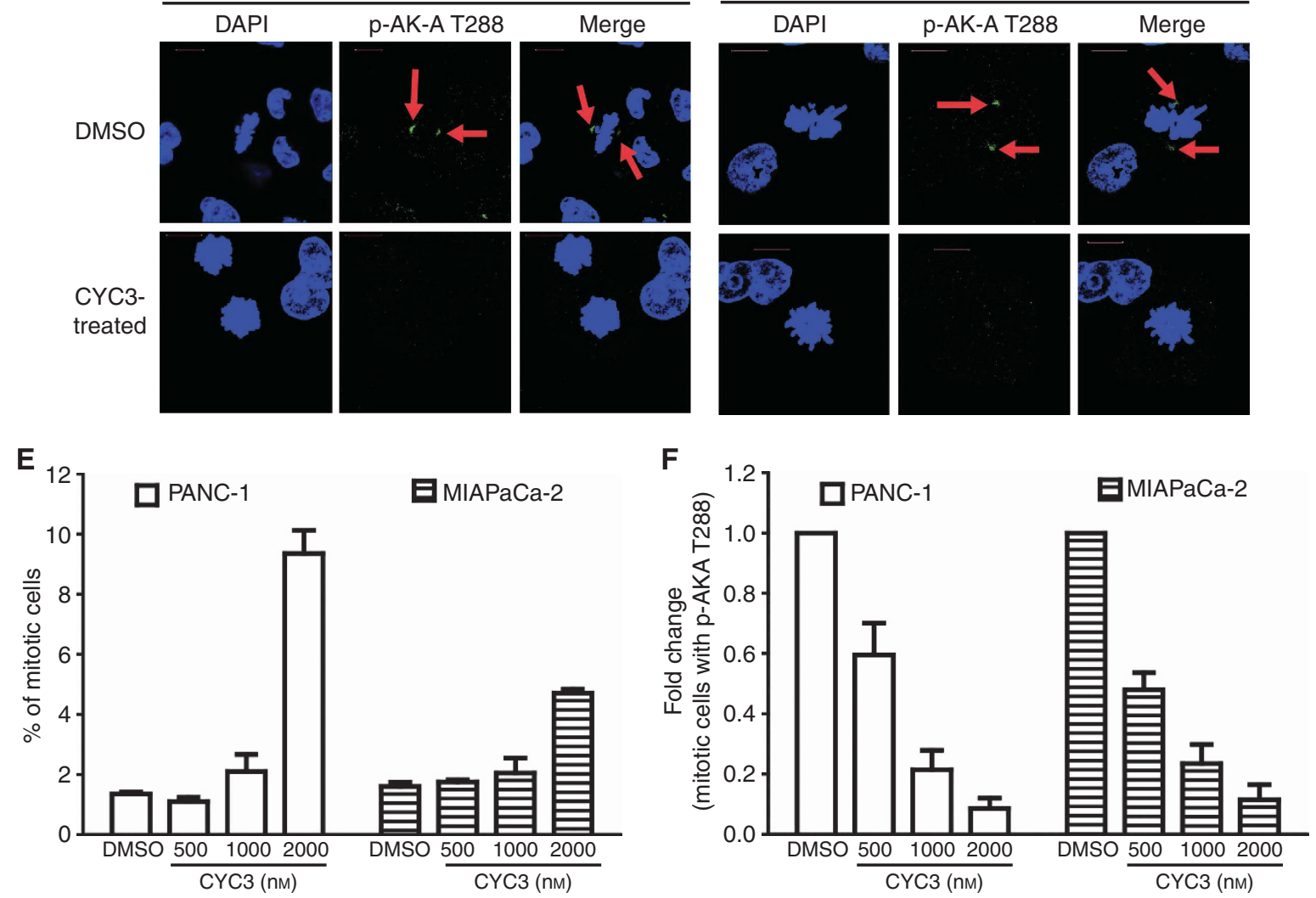

Figure I CYC3 specifically inhibits aurora kinase A activity in cells. (A, B) Cells were treated with $100 \mathrm{~nm}$ Nocodazole and DMSO, or indicated concentrations of CYC3 for $24 \mathrm{~h}$ before collecting. The protein expression levels were determined by western blot and quantified using ImageQuantTL. (C) Flow cytometry analysis of the cell cycle profiles of MIA PaCa-2 and PANC-I cells upon treatment with CYC3 as indicated. (D-F) Cells were treated with DMSO or indicated concentrations of CYC3 for $24 \mathrm{~h}$ before subjecting to immunofluorescent detection of p-AK-A T288 (arrows) and DAPI (scale bar $=25 \mu \mathrm{m}$ ). The fluorescent images are presented in $\mathbf{D}$. iCys research imaging cytometer was used to quantify the mitotic cells $(\mathbf{E})$, and mitotic cells with a positive staining of p-AK-A T288 (F). 
increase in the mitotic cell population (Figure 1E) and a dramatic decrease in the proportion of mitotic cells, which were p-AK-A T288-positive (Figure 1F), consistent with the observed cell cycle arrest and kinase inhibition (Figures $1 \mathrm{~A}-\mathrm{C}$ ).

After confirming that $\mathrm{CYC} 3$ functions as an AK-A-specific inhibitor in cells, the effect of CYC3 on cell survival was investigated in growth inhibition assays using SRB staining. CYC3 efficiently inhibited both MIA PaCa-2 and PANC-1 cell proliferation. The $72-\mathrm{h} \mathrm{GI}_{50}$ was $1.1 \mu \mathrm{M}$ for MIA PaCa-2 cells and $2 \mu \mathrm{m}$ for PANC-1 cells (Figure 2A). Next, we used time-lapse microscopy to compare the effect of $\mathrm{CYC} 3$ on cell growth over time. It is clear that CYC3 slows down the cell growth in both MIA PaCa-2 (Figure 2B) and PANC-1 (Figure 2C) cells in a dosedependent manner, with significant inhibition from $1.5 \mu \mathrm{m} \mathrm{CYC3}$ in both cell lines. In addition, increasing concentrations of CYC3 enhanced apoptosis in both MIA PaCa-2 (Figure 2D) and PANC-1 cells (Figure 2E) as measured by PARP cleavage, which is also consistent with previous publications about the cellular effects of AK-A-specific inhibition (Hata et al, 2005b; Warner et al, 2006). Phosphorylated histone $\mathrm{H} 3$ at the serine 10 site (p-H3 S10) is a marker of mitosis and AK-B activity (Gautschi et al, 2008). Increasing concentrations of $\mathrm{CYC} 3$ enhanced the expression of p-H3 S10 dramatically in PANC-1 cells (Figure 2E), but not in MIA PaCa-2 cells (Figure 2D), consistent with the greater increase in mitotic cells seen in PANC-1 in Figure 1E. Of note, CYC3 does not decrease $\mathrm{p}-\mathrm{H} 3 \mathrm{~S} 10$ in either cell line, which confirms that at concentrations $\leqslant 3 \mu \mathrm{m}$; CYC3 does not significantly inhibit AK-B. The anti-proliferative effect of $\mathrm{CYC} 3$ was confirmed in six additional cell lines from a variety of cancers, with a mean $\mathrm{IC}_{50}$ at $72 \mathrm{~h}$ of $2.3 \pm 1 \mu \mathrm{M}$ (Supplementary Table S2).
Synergy between CYC3 and low concentration of paclitaxel To fully evaluate the combination effects of paclitaxel and CYC3, $8 \times 8$ concentration combination experiments were performed in MIA PaCa-2 cells using SRB assays at $72 \mathrm{~h}$; investigating concentration ranges of $0.03-30 \mathrm{~nm}$ of paclitaxel and $0.25-3 \mu \mathrm{m}$ of CYC3. We then used the SynergySurface software to investigate how both drugs interact to inhibit growth in this data set. This approach identified that 1-3 nM paclitaxel with $0.25-1.5 \mu \mathrm{M}$ CYC3 inhibits growth more than expected under an additive effect assumption. However, there was no such synergy detected at higher concentrations of either agent (Figure 3A). The $E_{\max }$ (maximum growth inhibition within the area of synergy) was $89 \pm 7 \%$ growth inhibition at $1 \mu \mathrm{m} \mathrm{CYC} 3$ ( $\mathrm{IC}_{37}$ as single agent) +3 nм paclitaxel ( $\mathrm{IC}_{34}$ as single agent). In statistical analysis of the SRB data, the inhibitory effect of the $3 \mathrm{~nm}$ paclitaxel and $1 \mu \mathrm{M}$ CYC3 combination on MIA PaCa-2 cells is significantly different $(P<0.01)$ from the predicted addictive inhibition (Figure 3B). A similar synergistic region was found in PANC-1 cells, with $E_{\max }$ $70 \pm 16 \%\left(1 \mu \mathrm{M}\right.$ CYC3, $\mathrm{IC}_{13}$, and $3 \mathrm{~nm}$ paclitaxel, $\left.\mathrm{IC}_{49}\right)$.

To further validate the synergy, time-lapse microscopy was used to evaluate the effect of the combination on cell growth over time (Figure 3C). On the basis of the growth curves of cells treated with either $3 \mathrm{~nm}$ paclitaxel or $1 \mu \mathrm{m}$ CYC3 alone, an expected additive growth curve of the combination was calculated based on the Bliss Additivity Model. The experimental inhibition achieved using the combination suppressed the cell growth more than expected under the assumption of an additive effect of paclitaxel and CYC3. In MIA PaCa-2 cells, the cell confluence at $72 \mathrm{~h}$ in comparison with the initial cell confluence is $266 \pm 11 \%$, compared with an expected additive effect of $772 \%$ (Figure $3 \mathrm{C}$ ), whereas in PANC-1 cells it is
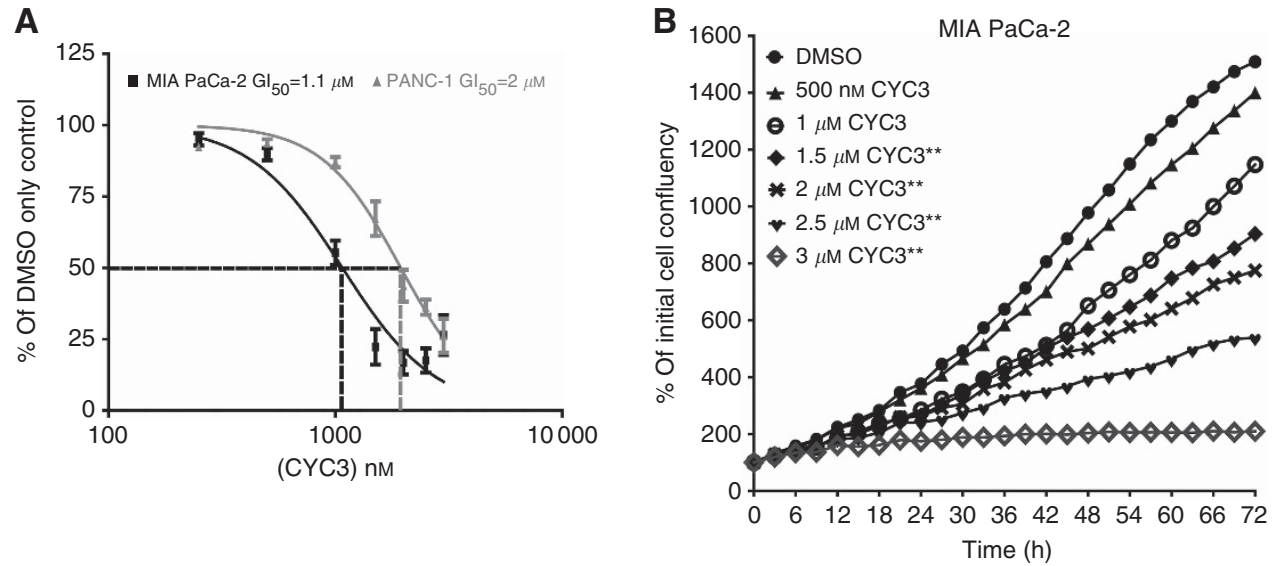

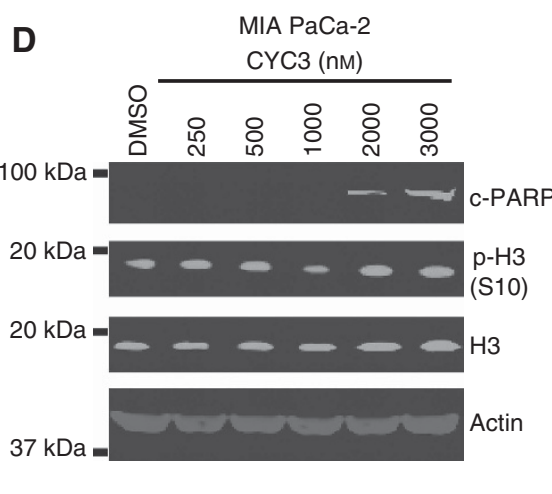

Figure 2 CYC3 inhibits cell growth and induces apoptosis. (A) MIA PaCa-2 and PANC-I cells were treated with CYC3, and the cells remaining after $72 \mathrm{~h}$ of treatment were measured by SRB assay. (B, C) Time-lapse microscopic measurement of the cell growth on treatment with CYC3. These data are the mean of two replicates (***means $P<0.01$ vs DMSO control). (D, E) Cells were treated with CYC3 as indicated for $24 \mathrm{~h}$ before collecting. The protein expression levels were determined by western blot. 
A

MIA PaCa-2

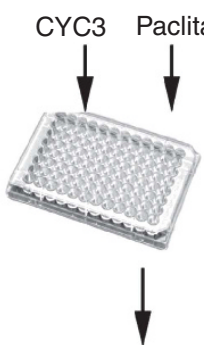

Data

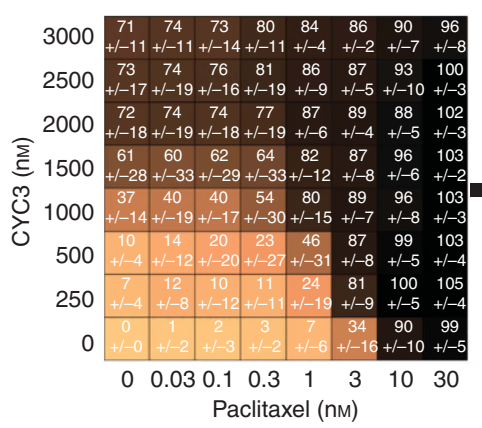

B

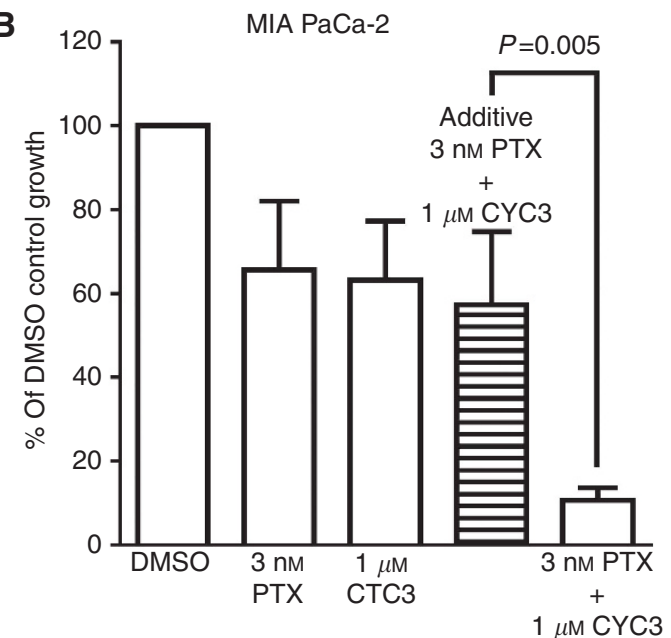

D MIA PaCa-2

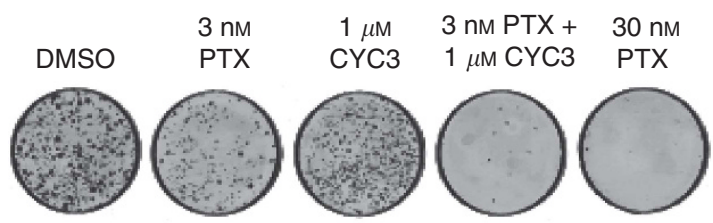

Single agents

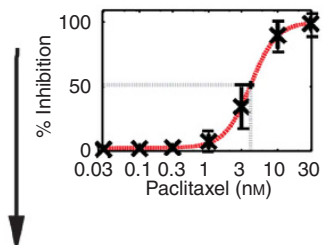

Bliss additivity model
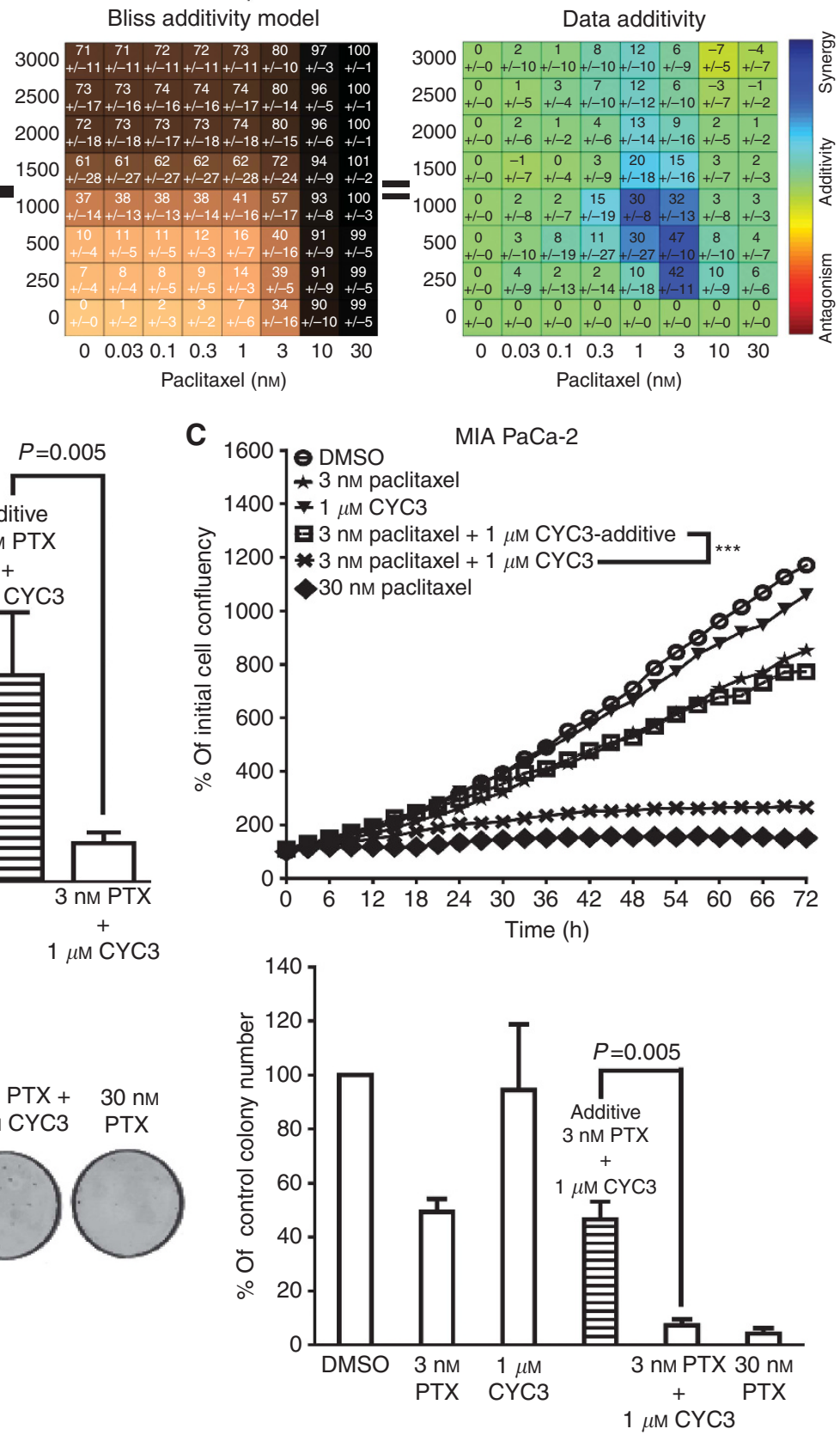

Figure 3 Evaluation of the effect of paclitaxel and CYC3 in combination. (A) MIA PaCa-2 cells were seeded in 96-well plates and treated with an $8 \times 8$ combinations of CYC3 and paclitaxel for $72 \mathrm{~h}$. The experimental data (mean of 6 replicates, left), the predicted inhibition by Bliss additivity model based on single-agent data (middle) and the difference value (Data additivity, right) tables are presented. The Synergy spots are in blue in the 'Data additivity' table. (B) Statistical analysis of the combination of $3 \mathrm{~nm}$ paclitaxel and I $\mu \mathrm{M}$ CYC3 in cells using SRB assays. Error bars represent the s.d. (C) Time-lapse microscopic measurement of the cell growth with CYC3 and paclitaxel as indicated. The predicted growth curve induced by additive suppression with 3 nM paclitaxel and I $\mu \mathrm{M}$ CYC3 is presented. These data are the mean of three replicates. ****interaction $P<0.000$ I, treatment difference $P=0.0007$. (D) Cells were incubated with paclitaxel and/or CYC3 for $72 \mathrm{~h}$, then plated in colony-forming assays. The left panels are the photos of the colony plates and the right panels are the quantification of the plates using ImageQuantTL. The predicted colony numbers induced by additive suppression with $3 \mathrm{~nm}$ paclitaxel and I $\mu \mathrm{M}$ CYC3 are presented. These data are the mean of six replicates. 
$236 \pm 2 \%$ vs $393 \%$ (Supplementary Figure S1A), supporting the existence of synergy between these two compounds. As a third test of synergy, a colony-formation assay was also used to evaluate the effect of the combination on cancer cell clonogenic ability (Figure 3D). On the basis of the effects of single agents, the Bliss additivity model was used to calculate the expected additive combination effect on colony formation. We detected a much greater inhibition of colony formation using the combination $(3.6 \pm 1.4 \%$ of control) than expected for using an additive combination (41.4\% of control) in the MIA PaCa-2 (Figure 3D) and PANC-1 cells $(13.2 \pm 6.5 \%$ of control vs predicted $39.1 \%$, Supplementary Figure S1B), which further confirms the synergistic interaction of $3 \mathrm{~nm}$ paclitaxel and $1 \mu \mathrm{M}$ CYC3 for inhibiting cell proliferation.

\section{Myelotoxicity of the combination treatment using CYC3 and paclitaxel}

A key question is if the combination will provide a better therapeutic window (i.e., lower myelotoxicity) when compared with the high-concentration single-agent activity of paclitaxel.

The potential myelotoxicity of the combination of $3 \mathrm{~nm}$ paclitaxel and $1 \mu \mathrm{m}$ CYC3 was compared with that seen with $30 \mathrm{~nm}$ paclitaxel, using the CFU-GM assay with human BM cells. Consistent with other reports (Kurtzberg et al, 2009), paclitaxel had a very steep dose response in colony inhibition from 3 to $10 \mathrm{~nm}$, suggesting there may be a threshold for paclitaxel toxicity in these progenitor cells (Figure 4A). In contrast, CYC3 demonstrated a shallow dose-dependent increase in toxicity (Figure 4B). The Bliss additivity model was used to calculate an additive combination effect on CFU-GM colony formation. The experimental colony inhibitory effect of $3 \mathrm{~nm}$ paclitaxel with $1 \mu \mathrm{m}$ CYC3 combination $(40.3 \pm 2.7 \%$ of control) was similar to the calculated additive inhibition (43.9 of control), whereas $30 \mathrm{~nm}$ paclitaxel treatment completely abolished all the colonies (Figure 4C). Thus, the combination of CYC3 and $3 \mathrm{~nm}$ paclitaxel was only additive in terms of toxicity to CFU-GM, whereas it was synergistic in toxicity to pancreatic cancer cells.

\section{Mechanism of the synergy}

Next, the mechanism underlying the synergy was explored further. The LC-MS spectrometry was used to investigate the cellular and media concentration of paclitaxel with or without CYC3 cotreatment in PANC-1 cells. When CYC3 was present, the cellular paclitaxel level was not significantly different from that observed in paclitaxel treatment alone (Figure 5A), suggesting CYC3 does not enhance the cellular uptake of paclitaxel.

The cell cycle arrest and apoptosis induction effects of the combination treatments were also investigated. Both $30 \mathrm{~nm}$ paclitaxel and the combination of $3 \mathrm{~nm}$ paclitaxel with $1 \mu \mathrm{m} \mathrm{CYC3}$ caused significant G2/M arrest in PANC-1 cells (Figure $5 \mathrm{~B}$ ), which is accompanied by an increase in $\mathrm{p}-\mathrm{H} 3 \mathrm{~S} 10$ phosphorylation (Figure 5D). Although in MIA PaCa-2 cells the induction of G2/M cell cycle arrest and p-H3 S10 phosphorylation by the same combination was less, there was an accompanying increase in the sub-G1 population, suggestive of apoptosis (Figures $5 B$ and $C$ ). Apoptosis was induced sooner in MIA PaCa- 2 cells $(24 \mathrm{~h})$ than in PANC-1 (48 h), as measured by PARP cleavage (Figures 5C and D). Apoptosis was confirmed by the detection of cleaved cytokeratin in the medium by M30 ELISA (Figure 5E and F, apparent at $48 \mathrm{~h}$ in MIA PaCa-2 vs $72 \mathrm{~h}$ in PANC-1). Thus, MIA PaCa-2 cells respond to the CYC3/paclitaxel combination with less stable arrest in mitosis and earlier apoptosis than in Panc-1, but in both cells the combination induces effective growth inhibition when measured at $72 \mathrm{~h}$.
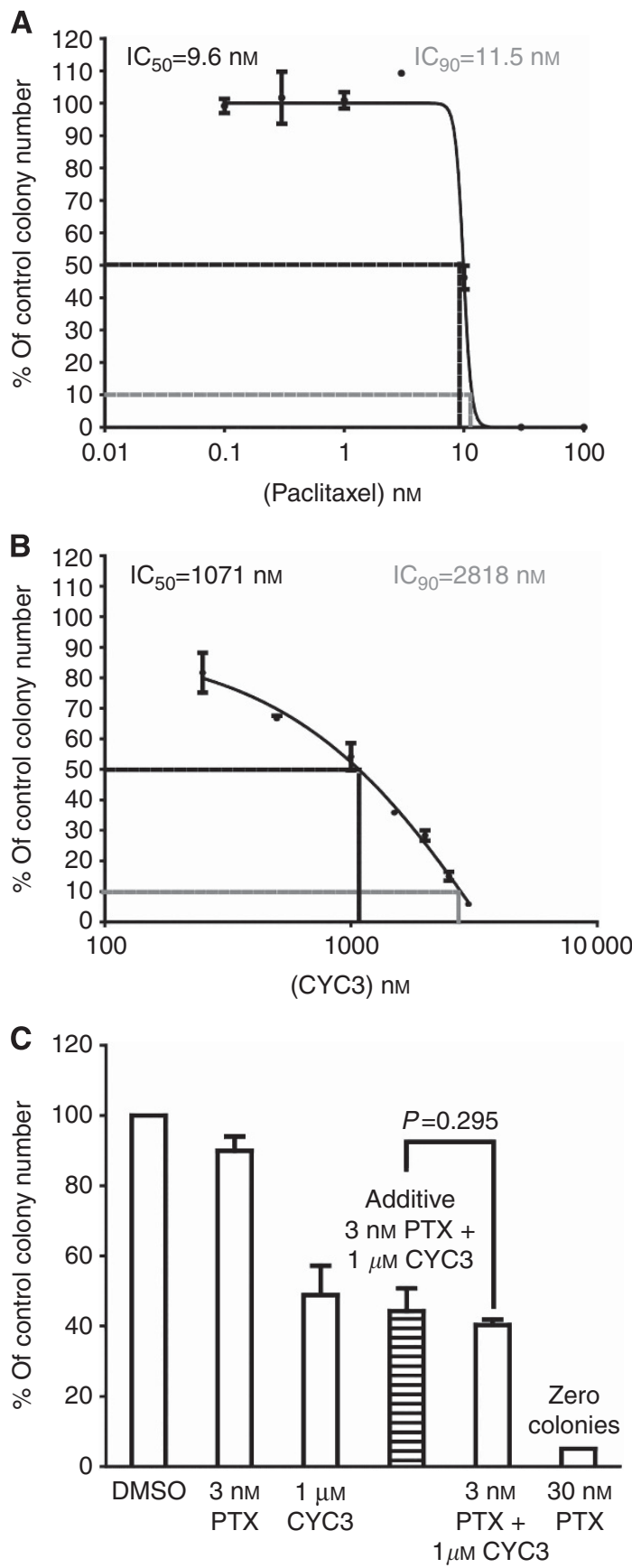

Figure 4 Effect of the combination of CYC3 and paclitaxel in CFU-GM assays. CFU-GM assays using human BM cells treated with paclitaxel $(\mathbf{A})$, CYC3 (B) and the combination of paclitaxel and CYC3 $(\mathbf{C})$. The predicted colony number induced by additive suppression with $3 \mathrm{~nm}$ paclitaxel and I $\mu \mathrm{M}$ CYC3 is presented in $(\mathbf{C})$. These data are the mean of three replicates.

\section{DISCUSSION}

CYC3 shows a 25 -fold differential between the in vitro activities against purified $\mathrm{AK}-\mathrm{A}\left(\mathrm{IC}_{50} 6 \mathrm{nM}\right)$ and $\mathrm{AK}-\mathrm{B}\left(\mathrm{IC}_{50} 154 \mathrm{~nm}\right)$. In comparison, MK-5108 (which was in clinical development) had an $\mathrm{IC}_{50}$ of $0.064 \mathrm{~nm}$ against $\mathrm{AK}-\mathrm{A}$ and $14.1 \mathrm{~nm}$ against $\mathrm{AK}-\mathrm{B}$ (Shimomura et al, 2010b), and MLN8237 has an $\mathrm{IC}_{50}$ of $1.2 \mathrm{~nm}$ against AK-A and $396.5 \mathrm{~nm}$ against AK-B (Manfredi et al, 2011a). In this study, we have demonstrated that the AK-A inhibitor CYC3 specifically inhibits AK-A activity in vitro in pancreatic cancer 
cells, arresting cells at mitosis, suppressing cell growth and inducing apoptosis.

We then investigated the activity of $\mathrm{CYC} 3$ in combination with paclitaxel. Many drug combination assays use the combinationindex isobologram method, which is based on the median effect principle developed by Chou and Talalay (1984), but this method tests fixed dose ratios of the two drugs, and we wished to investigate the full interaction surface across a broad range of concentrations of both drugs. The method developed by Chou and Talalay (1984) uses a line-fitting technique, but modern advances in numerical nonlinear solvers can determine the expected combined effect for any combination of inhibitor concentrations (Prichard and Shipman, 1990; Fitzgerald et al, 2006b). We chose to use a checkerboard design to investigate $8 \times 8$ dose combinations in a 96-well plate format. The relative proliferation associated with different drug concentrations was determined using the SRB assay
(Vichai and Kirtikara, 2006). We then developed a customed software, which automatically analyses the resulting combination data for synergistic effects, applying mathematical models to compare the predicted effect with the experimental data, using methods similar to those used by Prichard and Shipman (1990), and Prichard et al (1991). The mathematical models included in the software include the two most commonly used models for calculating the expected dose-response relationships from singleagent data: the Loewe additivity and Bliss independence. The Loewe additivity model assumes that two inhibitors act through a similar mechanism and, therefore, the resulting effect can be described by different equipotent dose ratios (Chou, 2006). The Loewe additivity model can describe the trivial situation that both agents are actually the same drug (Jonker et al, 2005), but to apply this mathematical method both agents have to show a typical dose-response relationship as single agents. In contrast, the Bliss
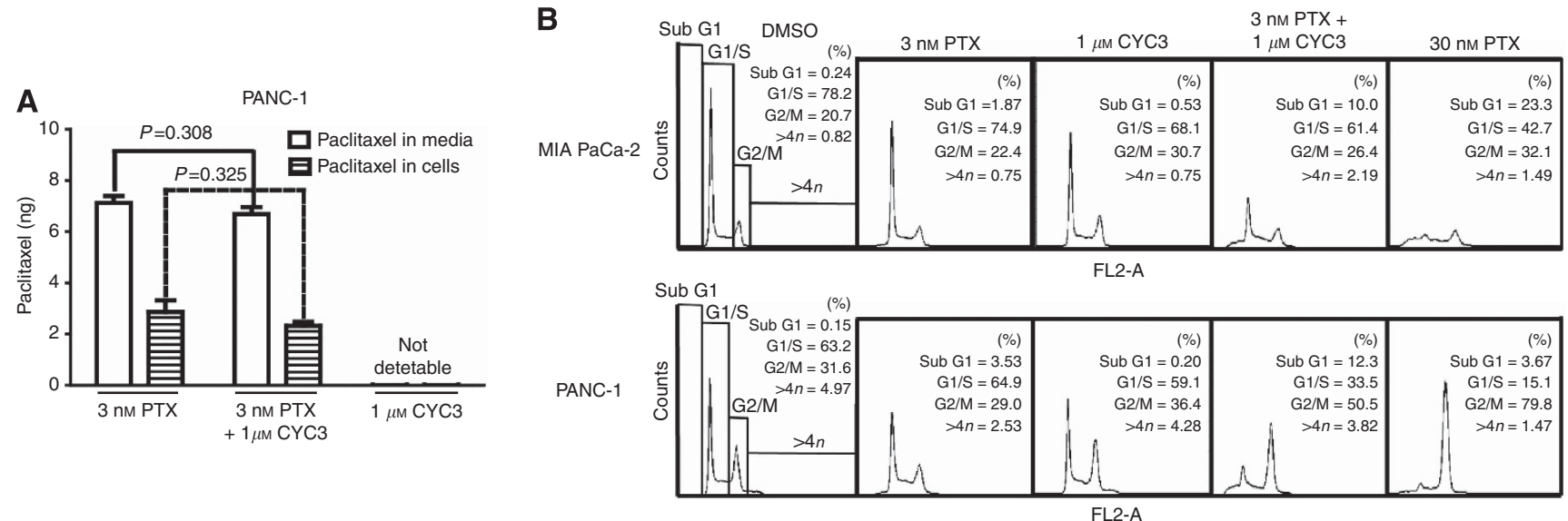

C

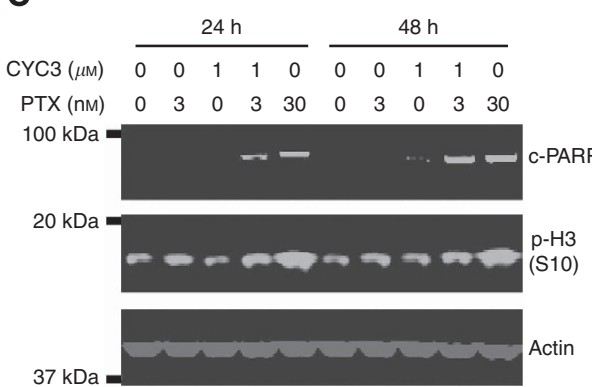

E

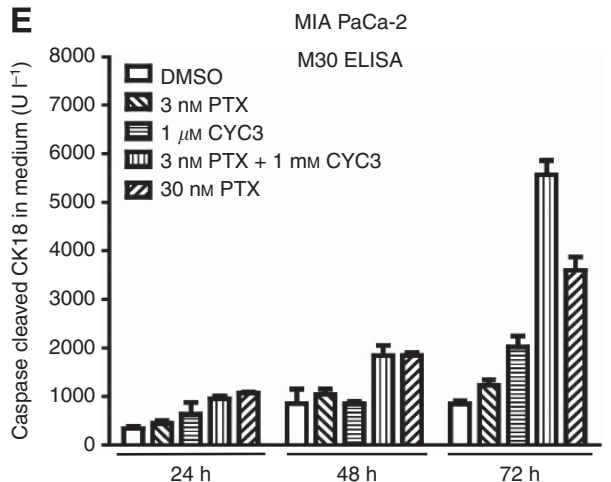

D

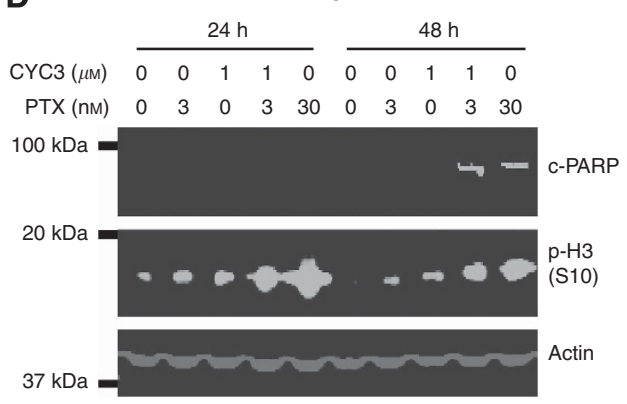

$\mathbf{F}$

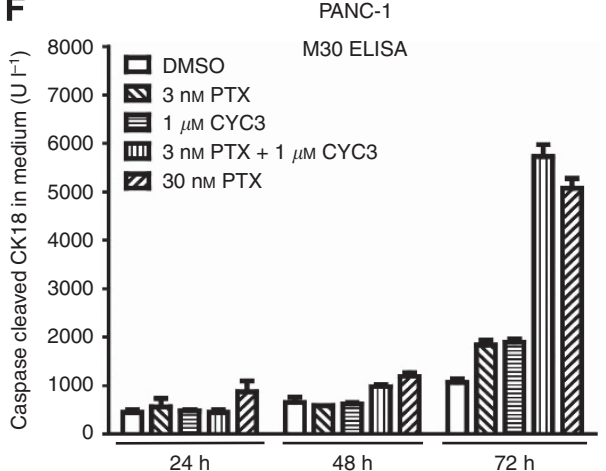

Figure 5 Investigation of the mechanism of the synergy between CYC3 and paclitaxel. (A) $0.5 \times 10^{6}$ PANC-I cells were seeded in $6-\mathrm{cm}$ dishes with $3 \mathrm{ml}$ DMEM media for $24 \mathrm{~h}$ before being treated with $3 \mathrm{~nm}$ paclitaxel \pm I $\mu \mathrm{M}$ CYC3 for $3 \mathrm{~h}$ before collecting. The amount of paclitaxel in cells and media were measured by LC-MS. (B) Flow cytometry analysis of the cell cycle profiles of cells upon treatments as indicated. (C, D) MIA PaCa-2 (C) and PANC-I (D) cells were treated as indicated for 24 and $48 \mathrm{~h}$ before collecting. The protein expression levels were determined by western blot. (E, F) MIA PaCa-2 (E) and PANC-I (F) cells were treated as indicated for 24,48 and $72 \mathrm{~h}$. The secreted caspases-cleaved keratin I 8 in the media was measured by M30 Apoptosense ELISA (Enzo Life Sciences). 
independence model assumes that both drugs modulate different mechanisms (Fitzgerald et al, 2006a). The Bliss independence model can be used on any data set, which describes a combination effect regardless of the shape of the single-agent dose-response curves, and this is the model we used in these studies. As the software is able to automatically analyse raw data output from plate readers, it allows us to test a large number of plates and concentration combinations more efficiently than other available software that requires pre-processing of the derived data (CompuSyn). This approach generates a 3D surface, which can be interrogated to identify regions of interaction.

Using the software to compare the experimental data with additivity predictions identified areas of synergy when $\mathrm{CYC} 3$ was combined with a low concentration of paclitaxel ( $3 \mathrm{~nm})$.

Our data are consistent with that of Hata et al (2005a) who showed in MIA PaCa-2 and PANC-1 cells that siRNA knockdown of AK-A enhanced cytotoxicity by $10 \mathrm{~nm}$ paclitaxel. Previous reports of the interaction between AK-A-specific inhibitors and taxanes in other cell types appear to be consistent. MK-5108 was shown to synergise with docetaxel to inhibit HeLa-S3 xenograft tumour growth (Shimomura et al, 2010b), and VE-465 was reported to synergise with paclitaxel to induce apoptosis in paclitaxel-resistant and -sensitive ovarian cancer cells (Scharer et al, 2008). In contrast, Wysong et al (2009) showed that inhibition of AK-A by MLN8054 abrogated the mitotic arrest induced by paclitaxel in colorectal and lung cancer cell lines by allowing mitotic slippage, because AK-A is required for spindle assembly checkpoint maintenance. However, these authors did not report the ultimate cell fate beyond $24 \mathrm{~h}$, so this is not necessarily contradictory to the synergistic cytotoxicity of the taxane/AK-A inhibitor combination. Also, the paclitaxel used in their study was $100 \mathrm{~nm}$, much higher than the synergistic 3-nM concentration we identified in our study. Indeed, in the experiments we report above, at high concentrations of paclitaxel ( $30 \mathrm{~nm})$, no synergy was observed. This highlights the importance of investigating wide ranges of concentrations of both agents, as described in this paper, to generate a surface of interaction, which can then be interrogated using modelling approaches.

By measuring the paclitaxel concentration in cells and in media, it was shown that CYC3 did not alter the uptake of paclitaxel. P-glycoprotein (P-gp, Mdr-1) is reported to be involved in drug resistance to paclitaxel by pumping paclitaxel out of the cells (Ueda et al, 1987a, b). Our result is consistent with a report in breast cancer cells showing AK-A inhibition does not influence the expression and function of P-gp ( $\mathrm{Li}$ et al, 2011), and suggests that a molecular mechanism underlies the synergy between paclitaxel and CYC3.

It is likely that the combination of $3 \mathrm{~nm}$ paclitaxel and $1 \mu \mathrm{m}$ CYC3 synergise to induce mitotic arrest and subsequent cell death. This hypothesis is consistent with the observations in PANC-1 cells, but the combination-induced mitotic arrest in MIA PaCa-2 cells was less obvious. However, the combination induced apoptosis sooner in MIA PaCa-2 than in PANC-1 cells. Therefore, a possible explanation for this cell line discrepancy may be that MIA PaCa-2 cells are more vulnerable to mitotic stress and cannot tolerate arrest in mitosis for as long as PANC-1 cells. Indeed MIA PaCa-2 and PANC-1 cells also displayed the same differential response to mitotic arrest by exposure to higher $(30 \mathrm{~nm})$ paclitaxel, and different cancer cell lines are known to vary in their response to prolonged exposure to anti-mitotic drugs (Gascoigne and Taylor, 2008). The molecular mechanisms underlying this cell line difference are not clear. Further investigations are needed, which may shed light on potential biomarkers for better responses to CYC3 alone and in combination with paclitaxel.

Having identified the areas of synergy, it was important to assess whether this might impact on the therapeutic index, when using combination strategies. Although inhibiting synergistically the growth and clonogenic ability of the cancer cells, the combination of $3 \mathrm{~nm}$ paclitaxel and $1 \mu \mathrm{M}$ CYC3 did not display synergistic toxicity towards CFU-GM human BM cells. Thus, there was a differential response between pancreatic cancer cells and human $\mathrm{BM}$ cells to the drug combination.

Of note, the combination of $3 \mathrm{~nm}$ paclitaxel and $1 \mu \mathrm{m} \mathrm{CYC} 3$ achieved a similar magnitude of cytotoxicity as treatment with higher ( $30 \mathrm{~nm})$ paclitaxel as a single agent in the cancer cell lines, but the combination was significantly less toxic than $30 \mathrm{~nm}$ paclitaxel in CFU-GM cells. These differences may reflect differences in the molecular action of paclitaxel at different concentrations; $10 \mathrm{~nm}$ paclitaxel has been shown to induce transient mitotic arrest followed by mitotic slippage in some cell lines, whereas $30 \mathrm{~nm}$ paclitaxel induced longer mitotic arrest without slippage (Riffell et al, 2009); these differences may be modulated by CYC3 in a different way in cancer cells with multiple genetic abnormalities than in normal CFU-GM cells. The mechanism of the difference in response of the cancer and normal cells warrants further investigation. These data suggest that the combination of CYC3 and low-dose paclitaxel could be associated with less myelotoxicity than higher doses of paclitaxel and yet be equally efficacious. This suggests that clinical trials of AKis with full-dose taxanes may fail because the taxane dose is too high. We plan to exploit this opportunity to 'resurrect' the AKi approach in pre-clinical and clinical trials, in combination with paclitaxel, using more rational, science-led dosing schedules.

\section{ACKNOWLEDGEMENTS}

We thank the core facilities in Cancer Research UK Cambridge Research Institute for the technical support, Ashok Venkitaraman (MRC/Hutchison Research Centre), Bob Jackson (Pharmacometrics), Masashi Narita and Mahito Sadaie (CRUK CRI) for the helpful discussion on the project, and Christina Ortmann (Department of Haematology, University of Cambridge) for the help to set up the CFUGM assay. This work was funded by Cancer Research UK.

\section{Conflict of interest}

Avril Robertson and Daniella Zheleva are employees of Cyclacel Ltd. Cyclacel provided the compound, but the laboratory costs were funded by Cancer Research UK.

Supplementary Information accompanies the paper on British Journal of Cancer website (http://www.nature.com/bjc)

\section{REFERENCES}

Anand S, Penrhyn-Lowe S, Venkitaraman AR (2003) AURORA-A amplification overrides the mitotic spindle assembly checkpoint, inducing resistance to Taxol. Cancer Cell 3(1): 51-62

Cheng Y, Prusoff WH (1973) Relationship between the inhibition constant $\left(K_{1}\right)$ and the concentration of inhibitor which causes 50 per cent inhibition $\left(I_{50}\right)$ of an enzymatic reaction. Biochem Pharmacol 22(23): 3099-3108

Cheung CH, Coumar MS, Hsieh HP, Chang JY (2009) Aurora kinase inhibitors in preclinical and clinical testing. Expert Opin Investig Drugs 18(4): 379-398
Chou TC (2006) Theoretical basis, experimental design, and computerized simulation of synergism and antagonism in drug combination studies. Pharmacol Rev 58(3): 621-681

Chou TC, Talalay P (1984) Quantitative analysis of dose-effect relationships: the combined effects of multiple drugs or enzyme inhibitors. Adv Enzyme Regul 22: 27-55

Dees EC, Infante JR, Cohen RB, O'Neil BH, Jones S, von Mehren M, Danaee H, Lee Y, Ecsedy J, Manfredi M, Galvin K, Stringer B, Liu H, Eton O, Fingert H, Burris H (2010) Phase 1 study of MLN8054, a selective 
inhibitor of Aurora A kinase in patients with advanced solid tumors. Cancer Chemother Pharmacol 67(4): 945-954

Diamond JR, Bastos BR, Hansen RJ, Gustafson DL, Eckhardt SG, Kwak EL, Pandya SS, Fletcher GC, Pitts TM, Kulikowski GN, Morrow M, Arnott J, Bray MR, Sidor C, Messersmith W, Shapiro GI (2011) Phase I safety, pharmacokinetic, and pharmacodynamic study of ENMD-2076, a novel angiogenic and Aurora kinase inhibitor, in patients with advanced solid tumors. Clin Cancer Res 17(4): 849-860

Fitzgerald JB, Schoeberl B, Nielsen UB, Sorger PK (2006a) Systems biology and combination therapy in the quest for clinical efficacy. Nat Chem Biol 2(9): 458-466

Fitzgerald JB, Schoeberl B, Nielsen UB, Sorger PK (2006b) Systems biology and combination therapy in the quest for clinical efficacy. Nat Chem Biol 2(9): 458-466

Gascoigne KE, Taylor SS (2008) Cancer cells display profound intra- and interline variation following prolonged exposure to antimitotic drugs. Cancer Cell 14(2): 111-122

Gautschi O, Heighway J, Mack PC, Purnell PR, Lara Jr PN, Gandara DR (2008) Aurora kinases as anticancer drug targets. Clin Cancer Res 14(6): 1639-1648

Hata T, Furukawa T, Sunamura M, Egawa S, Motoi F, Ohmura N, Marumoto T, Saya H, Horii A (2005a) RNA interference targeting aurora kinase a suppresses tumor growth and enhances the taxane chemosensitivity in human pancreatic cancer cells. Cancer Res 65(7): 2899-2905

Hata T, Furukawa T, Sunamura M, Egawa S, Motoi F, Ohmura N, Marumoto T, Saya H, Horii A (2005b) RNA interference targeting aurora kinase a suppresses tumor growth and enhances the taxane chemosensitivity in human pancreatic cancer cells. Cancer Res 65(7): 2899-2905

Jonker DM, Visser SA, van der Graaf PH, Voskuyl RA, Danhof M (2005) Towards a mechanism-based analysis of pharmacodynamic drug-drug interactions in vivo. Pharmacol Ther 106(1): 1-18

Kitzen JJ, de Jonge MJ, Verweij J (2010) Aurora kinase inhibitors. Crit Rev Oncol Hematol 73(2): 99-110

Kurtzberg LS, Roth SD, Bagley RG, Rouleau C, Yao M, Crawford JL, Krumbholz RD, Schmid SM, Teicher BA (2009) Bone marrow CFU-GM and human tumor xenograft efficacy of three tubulin binding agents. Cancer Chemother Pharmacol 64(5): 1029-1038

Li D, Zhu J, Firozi PF, Abbruzzese JL, Evans DB, Cleary K, Friess H, Sen S (2003) Overexpression of oncogenic STK15/BTAK/Aurora A kinase in human pancreatic cancer. Clin Cancer Res 9(3): 991-997

Li J, Wientjes MG, Au JL (2010) Pancreatic cancer: pathobiology, treatment options, and drug delivery. AAPS J 12(2): 223-232

Li Y, Tang K, Zhang H, Zhang Y, Zhou W, Chen X (2011) Function of Aurora kinase A in Taxol-resistant breast cancer and its correlation with P-gp. Mol Med Report 4(4): 739-746

Lok W, Klein RQ, Saif MW (2010) Aurora kinase inhibitors as anti-cancer therapy. Anticancer Drugs 21(4): 339-350

Macarulla T, Cervantes A, Elez E, Rodriguez-Braun E, Baselga J, Rosello S, Sala G, Blasco I, Danaee H, Lee Y, Ecsedy J, Shinde V, Chakravarty A, Bowman D, Liu H, Eton O, Fingert H, Tabernero J (2010) Phase I study of the selective Aurora A kinase inhibitor MLN8054 in patients with advanced solid tumors: safety, pharmacokinetics, and pharmacodynamics. Mol Cancer Ther 9(10): 2844-2852

Manfredi MG, Ecsedy JA, Chakravarty A, Silverman L, Zhang M, Hoar KM, Stroud SG, Chen W, Shinde V, Huck JJ, Wysong DR, Janowick DA, Hyer ML, Leroy PJ, Gershman RE, Silva MD, Germanos MS, Bolen JB, Claiborne CF, Sells TB (2011a) Characterization of Alisertib (MLN8237), an investigational small-molecule inhibitor of aurora A kinase using novel in vivo pharmacodynamic assays. Clin Cancer Res 17(24): 7614-7624

Manfredi MG, Ecsedy JA, Chakravarty A, Silverman L, Zhang M, Hoar KM, Stroud SG, Chen W, Shinde V, Huck JJ, Wysong DR, Janowick DA, Hyer ML, Leroy PJ, Gershman RE, Silva MD, Germanos MS, Bolen JB, Claiborne CF, Sells TB (2011b) Characterization of Alisertib (MLN8237), an investigational small-molecule inhibitor of aurora A kinase using novel in vivo pharmacodynamic assays. Clin Cancer Res 17(24): 7614-7624

Minton SE, LoRusso P, Lockhart AC, Saif MW, Krishnamurthi SS, PickettGies CA, Wang Y, Guan S, Roben E, Stein MN (2010) A phase I study of MK-5108, an oral aurora A kinase inhibitor, in both monotherapy and in combination with docetaxel in patients with advanced solid tumors. J Clin Oncol 28(Suppl): abstr e13026

Negro GD, Bonato M, Gribaldo L (2001) In vitro bone marrow granulocytemacrophage progenitor cultures in the assessment of hematotoxic potential of the new drugs. Cell Biol Toxicol 17(2): 95-105

Parent-Massin D (2001) Relevance of clonogenic assays in hematotoxicology. Cell Biol Toxicol 17(2): 87-94
Prichard MN, Prichard LE, Baguley WA, Nassiri MR, Shipman Jr C (1991) Three-dimensional analysis of the synergistic cytotoxicity of ganciclovir and zidovudine. Antimicrob Agents Chemother 35(6): 1060-1065

Prichard MN, Shipman Jr C (1990) A three-dimensional model to analyze drug-drug interactions. Antiviral Res 14(4-5): 181-205

Riffell JL, Zimmerman C, Khong A, McHardy LM, Roberge M (2009) Effects of chemical manipulation of mitotic arrest and slippage on cancer cell survival and proliferation. Cell Cycle 8(18): 3025-3038

Rojanala S, Han H, Munoz RM, Browne W, Nagle R, Von Hoff DD, Bearss DJ (2004) The mitotic serine threonine kinase, Aurora-2, is a potential target for drug development in human pancreatic cancer. Mol Cancer Ther 3(4): 451-457

Rowinsky EK, Eisenhauer EA, Chaudhry V, Arbuck SG, Donehower RC (1993) Clinical toxicities encountered with paclitaxel (Taxol). Semin Oncol 20(4 Suppl 3): 1-15

Scharer CD, Laycock N, Osunkoya AO, Logani S, McDonald JF, Benigno BB, Moreno CS (2008) Aurora kinase inhibitors synergize with paclitaxel to induce apoptosis in ovarian cancer cells. J Transl Med 6: 79

Sessa F, Mapelli M, Ciferri C, Tarricone C, Areces LB, Schneider TR, Stukenberg PT, Musacchio A (2005) Mechanism of Aurora B activation by INCENP and inhibition by hesperadin. Mol Cell 18(3): 379-391

Sharma S, Kurzrock R, Gouw L, Hong DS, Jones K, Zhou X, Shi H, Fingert $\mathrm{H}$, Falchook GS (2011) Phase I dose-escalation study of the investigational Aurora A kinase (AAK) inhibitor MLN8237 as an enteric-coated tablet (ECT) formulation in patients with nonhematologic malignancies. J Clin Oncol 29(Suppl): abstr 3094

Shimomura T, Hasako S, Nakatsuru Y, Mita T, Ichikawa K, Kodera T, Sakai T, Nambu T, Miyamoto M, Takahashi I, Miki S, Kawanishi N, Ohkubo M, Kotani H, Iwasawa Y (2010a) MK-5108, a highly selective Aurora-A kinase inhibitor, shows antitumor activity alone and in combination with docetaxel. Mol Cancer Ther 9(1): 157-166

Shimomura T, Hasako S, Nakatsuru Y, Mita T, Ichikawa K, Kodera T, Sakai T, Nambu T, Miyamoto M, Takahashi I, Miki S, Kawanishi N, Ohkubo M, Kotani H, Iwasawa Y (2010b) MK-5108, a highly selective Aurora-A kinase inhibitor, shows antitumor activity alone and in combination with docetaxel. Mol Cancer Ther 9(1): 157-166

Skehan P, Storeng R, Scudiero D, Monks A, McMahon J, Vistica D, Warren JT, Bokesch H, Kenney S, Boyd MR (1990) New colorimetric cytotoxicity assay for anticancer-drug screening. J Natl Cancer Inst 82(13): 1107-1112

Ueda K, Cardarelli C, Gottesman MM, Pastan I (1987a) Expression of a fulllength cDNA for the human 'MDR1' gene confers resistance to colchicine, doxorubicin, and vinblastine. Proc Natl Acad Sci USA 84(9): 3004-3008

Ueda K, Clark DP, Chen CJ, Roninson IB, Gottesman MM, Pastan I (1987b) The human multidrug resistance (mdr1) gene. cDNA cloning and transcription initiation. J Biol Chem 262(2): 505-508

Vichai V, Kirtikara K (2006) Sulforhodamine B colorimetric assay for cytotoxicity screening. Nat Protoc 1(3): 1112-1116

Wang S, Midgley CA, Scaerou F, Grabarek JB, Griffiths G, Jackson W, Kontopidis G, McClue SJ, McInnes C, Meades C, Mezna M, Plater A, Stuart I, Thomas MP, Wood G, Clarke RG, Blake DG, Zheleva DI, Lane DP, Jackson RC, Glover DM, Fischer PM (2010a) Discovery of N-phenyl4-(thiazol-5-yl)pyrimidin-2-amine aurora kinase inhibitors. J Med Chem 53(11): 4367-4378

Wang X, Sinn AL, Pollok K, Sandusky G, Zhang S, Chen L, Liang J, Crean CD, Suvannasankha A, Abonour R, Sidor C, Bray MR, Farag SS (2010b) Preclinical activity of a novel multiple tyrosine kinase and aurora kinase inhibitor, ENMD-2076, against multiple myeloma. Br J Haematol 150(3): 313-325

Warner SL, Munoz RM, Stafford P, Koller E, Hurley LH, Von Hoff DD, Han H (2006) Comparing Aurora A and Aurora B as molecular targets for growth inhibition of pancreatic cancer cells. Mol Cancer Ther 5(10): 2450-2458

Warshaw AL, Fernandez-del Castillo C (1992) Pancreatic carcinoma. N Engl J Med 326(7): 455-465

Wysong DR, Chakravarty A, Hoar K, Ecsedy JA (2009) The inhibition of Aurora A abrogates the mitotic delay induced by microtubule perturbing agents. Cell Cycle 8(6): 876-888

Zhang W, Dutschman GE, Li X, Cheng YC (2011) Quantitation of paclitaxel and its two major metabolites using a liquid chromatography-electrospray ionization tandem mass spectrometry. I Chromatogr B Analyt Technol Biomed Life Sci 879(22): 2018-2022

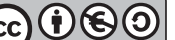

This work is licensed under the Creative Commons Attribution-NonCommercial-Share Alike 3.0 Unported License. To view a copy of this license, visit http:// creativecommons.org/licenses/by-nc-sa/3.0/ 